\title{
A 2D hydrodynamic-sedimentological model for gravel bed rivers. Part II, Case study: the Brenta River in Italy
}

\author{
Gabriel Kaless, ${ }^{1}$ Johnny Moretto, ${ }^{1}$ Fabio Delai, ${ }^{1}$ Luca Mao, ${ }^{2}$ Mario A. Lenzi' \\ ${ }^{1}$ Dipartimento Territorio e Sistemi Agroforestali, Università di Padova, Italy; ${ }^{2}$ Departamento de \\ Ecosistemas y Medio Ambiente, Pontificia Universidad Católica de Chile, Santiago, Chile
}

\begin{abstract}
A 2D depth average model has been used to simulate water and sediment flow in the Brenta River so as to interpret channel changes and to assess model predictive capabilities. The Brenta River is a gravel bed river located in Northern Italy. The study reach is 1400 long and has a mean slope of 0.0056 . High resolution digital terrain models has been produced combining laser imaging detection and ranging data with colour bathymetry techniques. Extensive field sedimentological surveys have been also carried out for surface and subsurface material. The data were loaded in the model and the passage of a high intense flood (R.I. > 9 years) was simulated. The model was run under the hypothesis of a substantial equilibrium between sediment input and transport capacity. In this way, the model results were considered as a reference condition, and the potential trend of the reach was assessed. Low-frequency floods (R.I. » 1.5 years) are expected to produce negligible changes in the channel while high floods may focalize erosion on banks instead than on channel bed. Furthermore, the model predicts well the location of erosion and siltation areas and the results promote its application to other reaches of the Brenta River in order to assess their stability and medium-term evolution.
\end{abstract}

Correspondence: Gabriel Kaless, TeSAF, Facoltà di Agraria, Università degli Studi di Padova, via dell'Università 16, 35020 Legnaro (PD), Italy.

Tel. +39.049 .8272675 - Fax. +39.049 .8272686 .

E-mail: gabriel.kaless@unipd.it

Key words: gravel-bed rivers, 2D depth-average model, hydrodynamic-sedimentological simulations, high-resolu-tion digital terrain models, Brenta River.

Acknowledgements: This research has been carried out within the frame of the UNIPD Project "CARIPARO-Linking geomorphological processes and vegetation dynamics in gravel bed rivers" and the UNIPD Strategic Project GEORISKS, Research Unit TeSAF Department. Part of this research was also founded by both, the SedAlp Project: Sediment Management in Alpine Basins: integrating sediment continuum, risk mitigation and hydropower, 83-4-3-AT, in the framework of the European Territorial Cooperation Programme Alpine Space 2007-2013, and the PRIN20104ALME4ITSedErosion: "National network for monitoring, modelling and sustainable management of erosion processes in agricultural land and hilly-mountainous area".

(C) Copyright G. Kaless et al., 2013

Licensee PAGEPress, Italy

Journal of Agricultural Engineering 2013; XLIV(s2):e20

doi:10.4081/jae.2013.s2.e20

This article is distributed under the terms of the Creative Commons Attribution Noncommercial License (by-nc 3.0) which permits any noncommercial use, distribution, and reproduction in any medium, provided the original author(s) and source are credited.

\section{Introduction}

Many gravel bed rivers in Italy have been disturbed over the last decades by human interventions. The recent changes of Brenta River have been analyzed by means of aerial photographs (Moretto, 2010). In other cases, such as the Piave River, the availability of historical documents has allowed the reconstruction of a chronology of changes in the last 200 years (Comiti et al., 2011). Human interventions have affected directly and indirectly the fluvial systems. Basin works such as reforestation, check-dams along tributaries and the construction of dams for electric energy generation purposes have severely reduced the sediment supply. Moreover, in-channel activities such as gravel mining and bank protections have also increased the sediment deficit (Surian and Rinaldi, 2003). Nowadays, there is the agreement that sediment supply change has been the key factor in determining channel adjustments (Rinaldi et al., 2005; Comiti et al., 2011). Hence, in most cases management strategies have been directed to operate on sediment supply for enhancing channel dynamics.

Sediment transport is not usually directly measured in large gravel bed rivers, and indirect strategies are employed instead. Up to the present, transverse sections have been surveyed and compared along the reaches of Brenta River (Surian and Cisotto, 2007) and Piave River (Comiti et al., 2011), involving standard GPS procedures. Recently, the combined use of laser imaging detection and ranging (LiDAR) data and elevation reconstruction by colour bathymetry techniques has produced high resolution digital terrain models (DTMs) which allow detailed studies at the reach scale (Moretto et al., 2012). Another strategy recently employed for the quantification of sediment transport has involved the use of numerical models. Ziliani and Surian (2012) have applied a cellular model for interpreting past changes in the Tagliamento River and to assess possible evolutionary trajectories according to different flow regime scenarios.

The aim of this paper is to interpret morphological changes at a reduced spatial and temporal scale occurred in a reach of the Brenta River, using a 2D-depth average hydrodynamic and sedimentological model. High resolution data have been elaborated and DTMs are available before and after an intense flood event (R.I. > 9 years).

\section{Brief history of the evolution of Brenta River}

As a result of the need of electric energy generation and new irrigation systems, during the first years of the $20^{\text {th }}$ century many dams were built, most of which were completed before the "60s (see Table 1). Dams have a scarce capacity for storing water volumes during flood events and, hence, to reduce the peak discharge. The main effect of dams has affected the regime of sediment delivery, interrupting the natural sediment flow during floods and, hence, affecting the sediment 
balance in the fluvial network placed downstream.

The decrease of sediment supply has also been a consequence of other human interventions, namely bank protection occurring mainly during the $19^{\text {th }}$ century and the implementation of torrent control works from the ' $20 \mathrm{~s}$, both promoting channel stability due to the increase of bank strength and fixing the stream bottom bed.

More recently, another human activity has altered the dynamics of these fluvial systems. Between the ' 60 s and ' 90 s, intense gravel mining was carried out. According to the official data, 8.6 million of cubic meters of sediments were supposed to have been mined between 1953 and 1977, but aerial photographs taken in those years indicate that the volume of sediments removed from the channel was much larger (Surian and Cisotto, 2007).

The Brenta River has experienced a dramatic narrowing process in the last decades, being $442 \mathrm{~m}$ wide at the beginning of $20^{\text {th }}$ century and reducing to $224 \mathrm{~m}$ in 2003 . This process has been accompanied by incision up to $2.5 \mathrm{~m}$. The mean channel slope has slightly increased, from $0.0033 \mathrm{~m} / \mathrm{m}$ to $0.0036 \mathrm{~m} / \mathrm{m}$ over the same period.

\section{Materials and methods}

The study reach of the Brenta River is placed $4.7 \mathrm{~km}$ downstream Bassano del Grappa, near to Nove village. The river reach is $1400 \mathrm{~m}$ long and the active channel is on average $73 \mathrm{~m}$ wide with a slope of 0.0056 . The mean depth accounts for $1.4 \mathrm{~m}$ with a maximum depth in the pools of $2.8 \mathrm{~m}$. The bed material (substrate) is composed by a gravel-sand mixture with $\mathrm{D}_{50}=21 \mathrm{~mm}$ and a sand content of $15 \%$. The bed is armoured and the surface layer is coarser than the substrate material $\left(\mathrm{D}_{50}=49 \mathrm{~mm}\right)$.

The Brenta River exhibits a single-thread channel which is mainly incised and has a floodplain confined by levees. Along the left bank protections, control works consisting on rip-rap inhibit channel widening; however, the right bank is free to evolve.

\section{Data acquisition and digital terrain model develop- ment}

The study reach of Nove was scanned with LiDAR technology at two different times: the $23^{\text {rd }}$ of August 2010 by Blom G.C.R. S.p.A. which used a sensor OPTECH ALTM Gemini; the $24^{\text {th }}$ of April 2011 by 0.G.S. which used a sensor RIEGL LMS-Q560. The raw LIDAR data were filtered to obtain ground points with the software "TerraScan". Because no bathymetric LiDAR surveys were available colour bathymetry method was used to create a more accurate and detailed DTM of the wetted areas. This methodology consists on calibrating a regression model between water level depth measurements, assessed by Differential Global Positioning System (DGPS), and Red, Green and Blue bands values of aerial photos taken contemporary to the LiDAR survey. Through the integration of LiDAR points for exposed areas and colour bathymetry points foreign-channel areas, the subsequent DTMs were compared creating a DoD (Digital elevation model of Difference) and identifying deposition and erosion processes. The accuracy of the models was then tested through DGPS control points (Moretto et al., 2012).

\section{Sedimentological surveys}

Samples of surface material were taken at 5 cross sections in order to describe the spatial variability (covering a sequence riffle-pool-rifflepool-riffle).The random walk approach (Wolman, 1954) was applied at each cross section collecting a minimum of 120 pebbles.

Two samples of substrate material were also taken from lateral bars.
The surface armour layer was removed and then the material was extracted; coarse pebbles were classified and weighted in the field and a sample of gravel and sand ( $<25 \mathrm{~mm}$ ) was later analyzed in the laboratory.

\section{Boundary conditions and numerical settings}

The Lican-Leufu model was employed for assessing the morphological evolution of the reach. The model solves the depth-averaged Reynolds's equations that incorporates the standard k-e model for turbulence closure. The sedimentological modulus solves the Exner's equation for bed elevation change and a two-layers scheme is used for modelling the armour layer (for further details see Kaless et al., 2013).

\section{Sediment supply}

A recirculation scheme was adopted so as to simulate a condition of mass balance, i.e., the reach can transport all the sediment supplied. Then, the stability state of the actual River Brenta could be assessed considering the model results as a reference of equilibrium.

\section{Water discharge}

The data available for the period 23/8/2010 - 24/4/2011 consisted of mean daily discharges, with a period length of 244 days. Since low discharges did not produce morphological changes, a minimum discharge of $150 \mathrm{~m}^{3} / \mathrm{s}$ was selected. This discharge can entrain at least $41 \%$ of the bed material (considering a reference dimensionless shear stress of 0.045). Discharges below $150 \mathrm{~m}^{3} / \mathrm{s}$ were removed from the original record but the sequence was conserved. The resulting record to be modelled had a length of 35 days.

\section{Numerical settings}

The domain was divided in 111 cells in the downstream direction and 60 cells across the channel. Cell sizes were not constant and averaged $12.60 \mathrm{~m}$ in length and between 2.00 to $4.00 \mathrm{~m}$ in width.

Although a short period of 35 days was simulated, the model was operated under the "medium-term" scheme (see Kaless et al., 2013). The discharge-tolerance was $10 \%$ and the tolerance for bed elevation change was set at $5 \%$. At the downstream boundary, a minimum bed elevation was imposed (no erosion could have taken place below this level) and the water surface elevation was fixed at the uniform-flow depth. The minimum water depth was set at $0.25 \mathrm{~m}$ for the hydrodynamic model and $0.30 \mathrm{~m}$ for the sedimentological routine.

On sites where banks are protected with rip-rap to prevent erosion, a high friction angle was set in the model (e.g. $\left.89^{\circ}\right)$.

\section{Results}

\section{Comparison of mass balance}

Cross sections were analyzed computing the volume difference between final and initial elevations. The difference has been expressed in terms of volumes (Figure 1). The predicted variation of volumes relies above the observed one, indicating that incision has taken place at the present condition of the Brenta River.

When the variation of volumes in the downstream direction is observed, it appears that both curves exhibit similar patterns. In order to evidence this fact, the model output was adjusted with a constant equal to the difference in predicted and observed total volumes. The 
dashed line in Figure 1 shows a good concordance for most of the reach. The first 15 cross sections exhibit clear differences: while erosion took place in the model, deposition was observed.

\section{Comparison of spatial patterns}

The DoD was calculated with the available DTMs of the Brenta River (Moretto et al., 2012) and the results of the simulation (Figure 2). The flow in the Brenta River was mainly concentrated in the active channel as indicated by the pattern of erosion/deposition, while all over the lateral floodplain a small erosion (10 $\mathrm{cm}$ on the mean) took place indicating conditions of lower flow. On the contrary, the lateral channel was activated in the simulation and a high erosion process took place at the upstream end.

Due to the passage of these high floods, bank erosion occurred along the pool sectors, i.e., the upper left bank (cross section 30) and the subsequent in the right bank (cross section 70). There should have been erosion on the next left side near cross section 90 but at this place bank was protected with rip-rap. Erosion was also significant on the right bank between sections 20 and 30 (see also Figure 2). This bank was not eroded in the simulation but at the same place erosion was present within the channel. However, it is evident the coincidence of erosion pattern with alternating sides, between observations and simulation.

Although the net mass balance is negative in the Brenta River, the DoD reveals that siltation also occurred within the channel. There was a large supply of material deposited at the upstream extremity of the reach, with positive mass balance at the beginning of the reach and modest net erosion downstream (see in Figure 1 the first 10 cross sections). Furthermore, downstream deposits were also generated immediately downstream the eroded sectors in the same side of the channel (see cross sections 70 and 90 in Figure 2). Since sediment was recirculated in the simulation, more material was available for bar formation and, hence, deposition sectors result more frequent in the predicted DoD. Those sectors observed in the field featuring siltation or low erosion are instead covered with sediments in the simulation, as shown between cross sections 50 and 100 .

Two cross sections were chosen for a local comparison. Figure 3 shows cross section 61 which was highly eroded during the flood events, in fact, the right bank retreated of about $11 \mathrm{~m}$. Siltation occurred along the opposite bank aggrading the bed level by nearly $1 \mathrm{~m}$. The model also predicted erosion in the same bank although it was not so significant as observed. Siltation was also correctly located on the left side of the channel with the same levels.

On the other hand, the comparison of the upstream cross section 50 results difficult because of the secondary channel activation during the simulation that diverted discharge and reduced the flow in the main channel. This fact, beside the imposition of a high friction angle for bank stability, may represent the reason of the lack of bank erosion sectors in the predicted cross section (Figure 4).

\section{Discussion}

The Brenta River has been dramatically disturbed by human activities during the last decades. Dams built in the upper basin have retained sediments in the catchment, protections works along the banks have limited the local sources of sediment and in-channel gravel mining has produced a deficit in sediment balance. The sediment dynamics in the Brenta River has recently been studied by Surian and Cisotto (2007). These researchers compared cross sections and aerial photographs and calculated sediment transport rates within the channel. As a result, they concluded that transport rate may range between $0-12.200 \mathrm{~m}^{3} / y e a r$ in the reach analyzed by this study.

There are some issues that should be considered before attempting

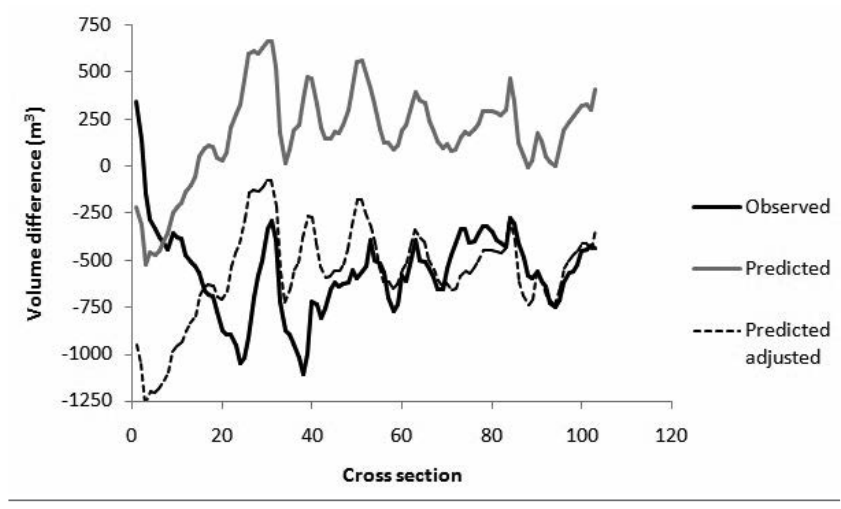

Figure 1. Comparison of mass distribution along the study reach. Volumes have been calculated considering the difference of DTMs at each cross section (see Figure 2 for location of sections).

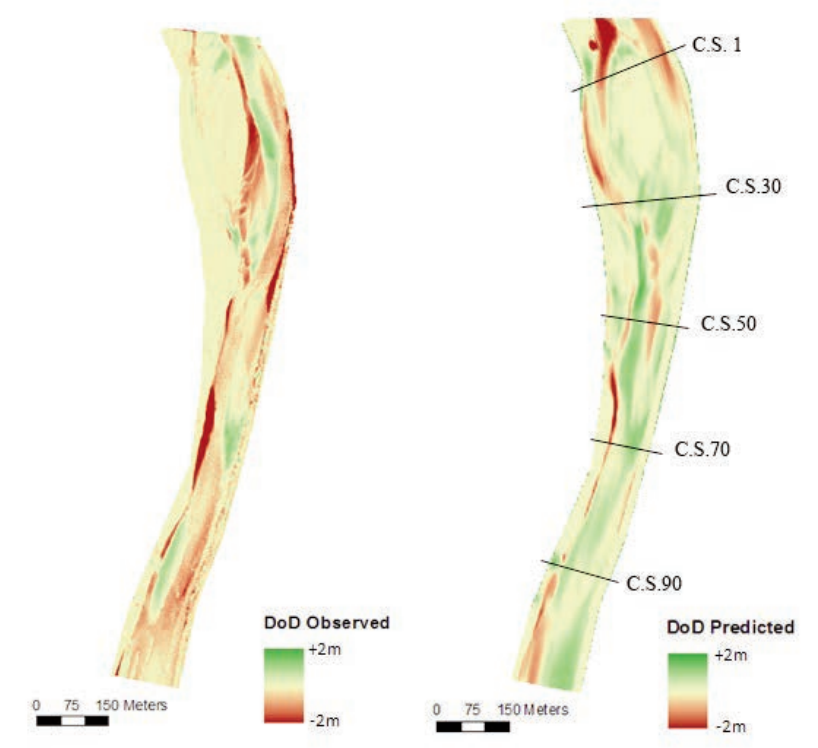

Figure 2. Comparison of measurements and model results. Left: Difference of DTMs measured in the field (Moretto et al., 2012); and right: Difference of DTMs simulated with the model. Cross sections (C.S.) are indicated.

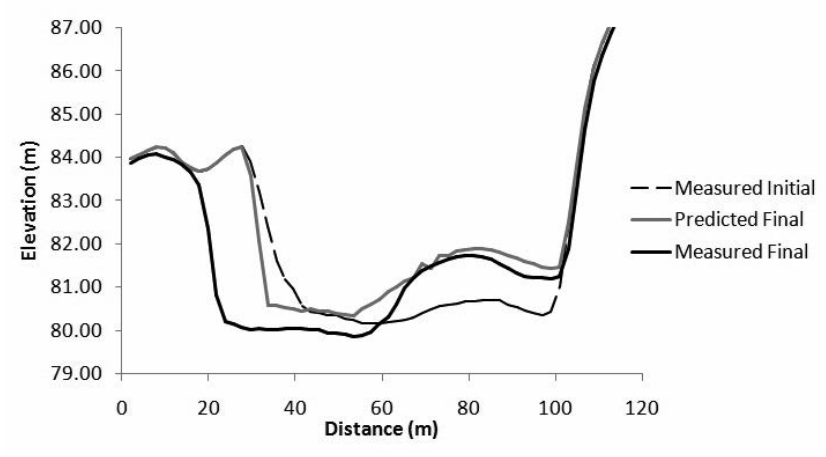

Figure 3. Comparison of a cross section with protection works on the right bank, at cross section 92 (see Figure 2 for location). 
a comparison of results. Firstly, there are spatial scales and data resolution differences between this study and the previously mentioned that have to be underlined. Surian and Cisotto evaluated sediment transport analyzing changes in 12 cross sections distributed along a 23 $\mathrm{km}$ long reach. In this study, high resolution DTMs were employed covering a shorter reach about $1400 \mathrm{~m}$ long. Secondly, these researchers did not consider the sand content because they assumed it was wash material. Subsurface surveys were conducted in this study indicating that sand content is $15.1 \%$. On the contrary, sediment transport and bed changes were computed in the numerical modelling using Wilcock and Crowe's (2003) model, which includes the sand fractions. Finally, the aforementioned input annual bulk of $12.200 \mathrm{~m}^{3}$ was added by the authors to the budget so as to have positive sediment transport; and they further indicated that at the Barzziza gauging station the total load was estimated in $37.000 \mathrm{~m}^{3} / y e a r$. Therefore, budgets provided by Surian and Cisotto will be considered as indication of "order of magnitude" and corrected to incorporate the sand content.

Total sediment volumes $\left(V_{T S}\right)$ are related with gravel volumes $\left(V_{\text {gravel }}\right)$ by means of:

$$
V_{T S}=\frac{V_{\text {gravel }}}{(1-S F)}
$$

where in SF is the sand content. DoD volumes () are also corrected to take into consideration porosity:

$$
V_{T s}=(1-\lambda) \cdot V
$$

Surian and Cisotto reported a sand content of $20.8 \%$ and hence their informed volumes were multiplied by 1.263 . The bed porosity was estimated using an empirical formula proposed by Wu and Wang (2006) accounting for 0.241 Hence volume differences have to be multiplied by the factor 0.759 .

The model was run under conditions of mass balance, i.e., the reach transport capacity was equal to the sediment supply. Figure 5 shows the sediment transport rate for different discharges as predicted by the model. According to the model, transport rate increases lowly up to discharges above bankfull, but surpassing a discharge of $380 \mathrm{~m}^{3} / \mathrm{s}$, transport rate goes up quickly.

The mean annual sediment transport rate was calculated using the duration curve of discharges for the last 50 years, and resulted to be $77.210 \mathrm{~m}^{3}$. The recirculated total sediment volume for the studied events was $160.000 \mathrm{~m}^{3}$, i.e., the required volume for mass balance during these events could not be supplied with the ordinary curve of discharges. Furthermore, if the calculated transported discharge is adopted as an estimation of the actual sediment transport, then the sediment supplied can also be assessed. The difference in the DTMs indicates that the reach lost $57.810 \mathrm{~m}^{3}$ and hence the supply should be in the order of $10^{5} \mathrm{~m}^{3}$, which is one order of magnitude higher than the
Surian and Cisotto estimation for the annual transport rate of 15.400 $\mathrm{m}^{3} / 37.000 \mathrm{~m}^{3}$.

Erosion along the active channel may be conditioned by several factors: channel widening, the development of a static armour, or by fixing the boundary conditions at the bridge located near downstream of the reach. Figure 2 shows that most part of the material deficit was due to erosion along the banks of the channel. Computing the volumes it turned out that bank erosion furnished $21.750 \mathrm{~m}^{3}$ of material during the floods, which is $38 \%$ of the total mass deficit. One possible river restoration scenario could entail the elimination of protection works existing along the right bank at the downstream part of the reach, where it would be possible to relocate three houses and to build a new

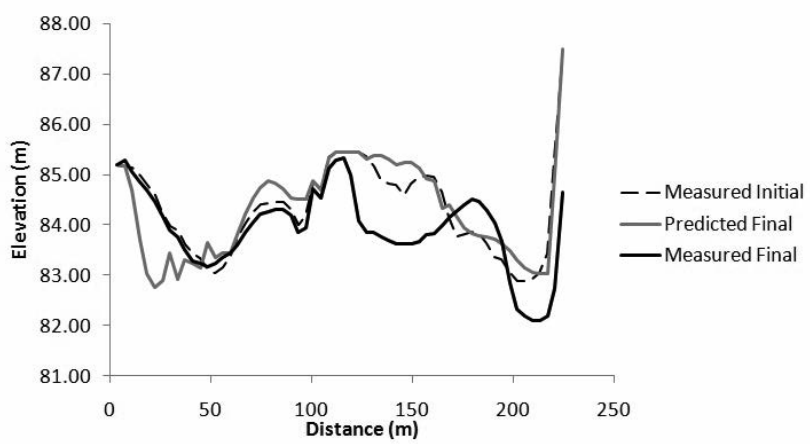

Figure 4. Evolution of the historical cross section after the passage of floods in the period 2010-2011. See cross section 30 in Figure 2 for location.

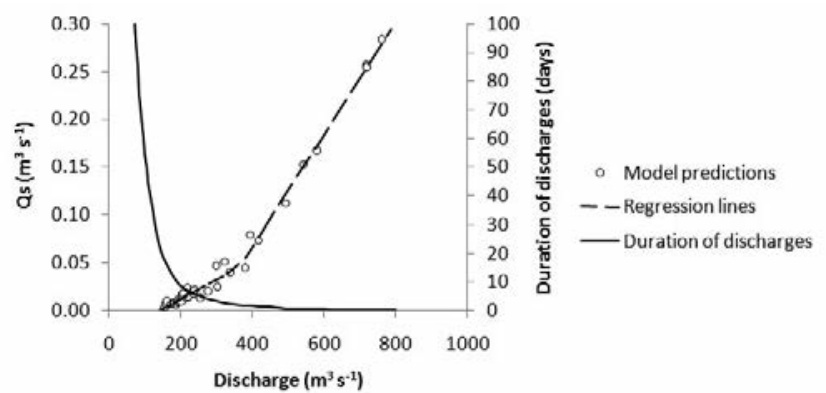

Figure 5. Predicted sediment transport rate in the Brenta River for the simulated period. Frequency of discharges was calculated using records from the last 50 years.

Table 1. Dams constructed in the Brenta River basin. The drainage area upstream the dam is indicated (modified from Surian and Cisotto, 2007).

\begin{tabular}{llcc} 
River & Dam & Drainage area upstream $\left(\mathrm{km}^{2}\right)$ & Year of construction \\
Cismon Torrent & Ponte Serra & 497 & 1909 \\
Costa Brunella Torrent & Costa Brunella & 0.7 & 1941 \\
\hline Cismon Torrent & Corlo & 628 & 1954 \\
Senaiga Torrent & Senaiga & 58 & 1954 \\
\hline Noana Torrent & Val Noana & 8 & 1958 \\
Cismon Torrent & Val Schener & 204 & 1963 \\
\hline
\end{tabular}


levee $100 \mathrm{~m}$ to $150 \mathrm{~m}$ apart from the current bank position. Under this scenario, channel widening would promote channel stability by providing material and reducing the transport capacity as shear stress would reduce. A recent research carried on by Rigon et al. (2012) has pointed out the relation between flood magnitude and channel widening, and stressed the role of riparian vegetation. In general, a higher magnitude of flooding corresponds to a higher active channel widening; and a reduction of the active channel width is due to the expansion of riparian vegetation establishing in floodplains and islands during periods of lack of major disturbance processes.

The development of a static armour is crucial for the channel stability. Laboratory experiments revel that two phases are present during the development of the armour: a first phase of incision and a second phase of coarsening (Church et al., 1998; Wilcock et al., 2001; Mao et al., 2011). Furthermore, static amour layers are highly structured and imbricated with higher thresholds for entrainment. The Brenta River is highly armoured, with a reach-average absolute armouring index of 2.32 (3.58 at riffles and 1.72 at pools). Considering reach-average values, the surface $\mathrm{D}_{90}$ is nearly $181 \mathrm{~mm}$ and the maximum diameter $\left(\mathrm{D}_{99}\right)$ is $335 \mathrm{~mm}$. This surface material is much coarser than the competence of high flows (RI > 9 years) which according to the model is $\mathrm{D}_{90}=73$ $\mathrm{mm}$ and $\mathrm{D}_{99}=155 \mathrm{~mm}$. This difference may be an indication that the surface has developed a static armour that is resistant to high floods.

\section{Conclusions}

The 2D-depth average model described well the location of siltation areas and bank erosion, although it was run under a condition of unlimited sediment supply which was not the actual situation in the Brenta River. The applied model, based on high-resolution DTMs, estimated annual sediment transport in the order of $8 \cdot 10^{4} \mathrm{~m}^{3}$ which is higher in respect to previous studies results based on cross sections.

The response of the channel in the medium-term has to distinguish ordinary events (above bankfull discharge, with $Q=350 \mathrm{~m}^{3} / \mathrm{s}$ and R.I. »1.5 years) and high floods with recurrence interval above 9 to 10 years. With regards to ordinary events, due to the presence of a well armoured bed and low transport rates, not significant or negligible changes are expected to be observed in the channel bed (considering also errors in determination of volume changes that render difficult to discern small changes). On the other hand, high floods are expected to focalize erosion on banks instead on channel bed.

In general, the model provided good results that promote its application to other reaches of the Brenta River in order to assess their stability and medium-term evolution.

\section{References}

Church M, Hassan MA, Wolcott JF. Stabilizing self-organized structures in gravel-bed stream channels: field and experimental observations, Water Resour Res 1998; 34, 3169-79.

Comiti F, Da Canal M, Surian N, Mao L, Picco L, Lenzi MN. Channel adjustments and vegetation cover dynamics in a large gravel bed river over the last 200 years, Geomorphology 2011, doi: 10.1016/j.geomorph.2010.09.011.

Kaless G, Lenzi MA, Mao L. A 2D hydrodynamic-sedimentological model for gravel bed rivers. Part I: theory and validation. Proceedings of the Italian Society of Agricultural Engineering Associazione Italiana, 2013; In Press.

Mao L, Cooper J, Frostick L. Grain size and topographical differences between static and mobile armour layers. Earth Surf Processes 2011, DOI: 10.1002/esp.2156.

Moretto J. Caratterizzazione dei fliumi ghiaiosi naturali ed antropizzati e analisi delle modificazioni morfologiche più recent del Fiume Brenta tra Bassano del Grappa e Carturo. Degree Diss. Università degli Studi di Padova, Italy; 2010.

Moretto J, Rigon E, Mao L, Delai F, Picco L, Lenzi MA. Assessing morphological changes in gravel bed rivers using LiDAR data and colour bathymetry. Erosion and Sediments Yields in the Changing Environments, Proceedings of a symposium held at the Institute of Mountain Hazards and Environment 2012. IAHS Publ. 356, 419-427.

Rigon E, Moretto J, Mao L, Picco L, Delai F, Ravazzol D, Lenzi MA, Kaless G. Thirty years of vegetation cover dynamics and planform changes in the Brenta River (Italy): implications for channel recovery. Erosion and Sediments Yields in the Changing Environments, Proceedings of a symposium held at the Institute of Mountain Hazards and Environment 2012. IAHS Publication 356, 178-86.

Rinaldi M, Wyzga B, Surian N. Sediment mining in alluvial channels: physical effects and management perspectives. River Res Appl 2005; 21: 805-28.

Surian N, Rinaldi M. Morphological response to river engineering and management in alluvial channels in Italy. Geomorphology 2003; 50, 307-26.

Surian N, Cisotto A. Channel adjustments, bedload transport and sediment sources in a gravel-bed river, Brenta River, Italy. Earth Surf Processes 2007; 32, 1641-56.

Wilcock PR, Kenworthy ST, Crowe J. Experimental study of the transport of mixed sand and gravel. Water Resour Res 2001; 37, 3349-58.

Wilcock PR, Crowe JC. Surface-based transport model for mixed-size sediment, J Hydrol Eng 2003; 129, 120-8.

Wolman MG. A method of sampling coarse bed material. American Geophysical Union, Transactions 1954; 35, 951-6.

Ziliani L, Surian N. Evolutionary trajectory of channel morphology and controlling factors in a large gravel-bed river. Geomorphology 2012; doi:10.1016/j.geomorph.2012.06.001. 